\title{
A aplicação de medidas cautelares pessoais em audiências de custódia: um olhar a partir da prisão em flagrante de pessoas em situação de rua ${ }^{1}$
}

\author{
Provisional measures' application in custody hearings: \\ a study based on homeless people' arrests
}

\section{Vinícius de Assis Romão ${ }^{2}$}

\author{
Universidade do Estado do Rio de Janeiro - Rio de Janeiro - Brasil \\ vinicius.romao23@gmail.com \\ http://lattes.cnpq.br/1405019334868567 \\ https://orcid.org/0000-0001-8271-7694
}

\begin{abstract}
Resumo: O artigo partiu da pergunta: como ocorre a aplicação de medidas cautelares pessoais nos encontros presenciais entre atores jurídicos e pessoas em situação de rua em audiências de custódia? Realizou-se pesquisa de campo no Núcleo de Prisão em Flagrante e Audiências de Custódia de Salvador, em dois períodos do ano de 2018, coletando dados em distintos contextos de demanda por ordem na cidade, para entender os sentidos conferidos por juízes, promotores e defensores em relação às medidas cautelares em espécie. Dentre a observação de audiências com 69 custodiados, a pesquisa teve como amostra operacional casos de 19 pessoas em situação de rua. Em relação a estes, também foi realizada análise documental dos 19 autos de prisão em flagrante e 52 processos pretéritos, entre ações penais e autos de prisão em flagrante, que constavam como registros criminais. Expandindo
\end{abstract}

1 O presente trabalho foi realizado com apoio da Coordenação de Aperfeiçoamento de Pessoal de Nível Superior - Brasil (CAPES) - Código de Financiamento 001.

2 Doutorando e mestre pela Universidade do Estado do Rio de Janeiro (UERJ). Especialista em Ciências Criminais pela Pontifícia Universidade Católica de Minas Gerais (PUC-MG). Bacharel em Direito pela Universidade Federal da Bahia (UFBA). Membro do Grupo Clandestino de estudos em controle, cidade e prisões. Associado ao Instituto Baiano de Direito Processual Penal (IBADPP). Professor de processo penal e criminologia e advogado criminalista. 
a análise para além da mera ausência ou insuficiência de fundamentação nas decisões e analisando a técnica do "paredão" como procedimento informal de audiência, problematizou-se as funções não declaradas que vêm sendo atribuídas às medidas cautelares, a depender do contexto de demanda punitiva, e a conformação da lógica da "prisão a médio prazo". O trabalho conclui que as medidas tidas como alternativas, além de não serem debatidas sob os critérios legais de cautelaridade, exercem uma função de antecipação punitiva e se inserem na gestão sociorracial urbana, apresentando conexões mais profundas com a prisão preventiva, que é mantida em seu horizonte.

Palavras-chave: Medidas cautelares diversas da prisão; Audiência de custódia; Pessoas em situação de rua; atuação judicial.

ABSTRACT: The article's question is about how provisional measures are applied in encounters between legal actors and homeless people in custody hearings, based on the procedural of debating and deciding. Data collection took place at the Núcleo de Prisão em Flagrante e Audiências de Custódia in Salvador, in two periods of the year 2018, to understand the meanings conferred by judges, prosecutors and defenders regarding provisional measures in kind. Among the observation of hearings with 69 in custody, the research had as an operational sample cases of 19 people living on the streets. In relation to these, a documentary analysis was also carried out of the 19 flagrant arrest records and 52 past cases, including criminal actions and flagrant arrest records, which were recorded as criminal records. Expanding the analysis beyond the mere absence or insufficiency of reasoning in the decisions and analyzing the "paredão" technique as an informal hearing procedure, the hidden features that have been attributed to the provisional measures were analyzed, in each context of punitive demand, along the logic of "perspective prison". The work concludes that the measures considered as alternatives, in addition to not being discussed under the legal criteria, exercise a punitive anticipation function and are inserted in the urban socio-racial management, presenting deeper connections with the pre-trial prison, which is maintained in its horizon.

KeYwords: Provisional Measures; Custody Hearings; Homeless people; Judicial procedure.

SUMÁRIO: Introdução; 1. Entre debates orais e decisões judiciais: observação de audiências de custódia e análise de autos de prisão em flagrante; 2 . Além da soltura: pensando as medidas cautelares 
diversas após a implementação das audiências de custódia; 3 . Atores jurídicos na gestão de medidas cautelares específicas e a lógica da "prisão a médio prazo". 3.1. Os sentidos das medidas cautelares pessoais nas interações em audiências de custódia: o que escapa dos registros oficiais. 3.2. O controle da circulação mediado pelo judiciário: algumas pistas a partir da cautelar "proibição de acesso ou frequência a determinados lugares". 3.3. Entre a aplicação automatizada e a "insuficiência as medidas cautelares": a relegitimação do cárcere na lógica da "prisão a médio prazo". Considerações Finais; Referências.

\section{INTRODUÇão}

As audiências de custódia foram implementadas em 2015, visando garantir o cumprimento da Convenção Americana de Direitos Humanos e do Pacto Internacional de Direitos Civis e Políticos, dos quais o Brasil é signatário desde 1992, conforme os decretos 678/1992 e 592/1992. O acórdão do Supremo Tribunal Federal (STF) na ADPF 347 determinando a obrigatoriedade da realização das audiências conferiu maior legitimidade para a Resolução no 213/2015 do Conselho Nacional de Justiça (CNJ). O órgão mobilizou o judiciário a fim de possibilitar o cumprimento das finalidades primordiais do instituto processual: a cessação de atos de maus tratos ou tortura e a promoção de um espaço democrático de discussão sobre a legalidade da prisão, com análise do cabimento, da necessidade e da proporcionalidade de aplicação de medidas cautelares, preferencialmente, diversas da prisão (PAIVA; LOPES JR., 2014).

Com a Resolução $n^{\circ}$ 26/2015 do Tribunal de Justiça da Bahia (TJBA), a cidade de Salvador, que já tinha o Núcleo de Prisão em Flagrante (NPF), foi uma das primeiras a realizar audiências de custódia à luz do rito procedimental prescrito pelo CNJ. Neste cenário, o contato presencial obrigatório entre juízes, promotores, defensores e pessoas presas em flagrante abriu caminhos de investigação sobre a prática dos atores processuais ${ }^{3}$ quando se decide o destino de alguém que tenha sido preso em flagrante.

Nesta pesquisa, a expressão “atores processuais” será utilizada como sinônimo de "atores jurídicos" e "atores institucionais" para se referir a promotores, 
O contexto de recrudescimento punitivo, na conjuntura de avanço neoliberal, é marcado pelo grande encarceramento que, na América Latina, é sustentado pelo uso indiscriminado da prisão preventiva contra sujeitos pertencentes a históricas categorias de indesejáveis ou "classes perigosas", conformando o que Zaffaroni (2011) chamou de sistema penal cautelar. Contudo, conforme ampla literatura criminológica, a tentativa de adoção de medidas alternativas penais ou à prisão acabaram tendo mais efeito de ampliar as teias do sistema punitivo do que de reduzir o uso da prisão (COHEN, 1979; CARVALHO, 2010a; KARAM, 2010).

No campo do processo penal, a reforma promovida pela Lei 12.403/2011 acabou promovendo um indesejado desvirtuamento das alternativas à prisão, risco que já era apontado como pela doutrina, haja vista a tradição inquisitorial que modela atuação de grande parte dos atores jurídicos (CARVALHO, 2010b; LOPES JR, 2013; VASCONCELLOS, 2013). Em relação às audiências de custódia, diversos relatórios institucionais e pesquisas acadêmicas ${ }^{4}$ vêm apontando desde o início da sua implementação pelo CNJ, as limitações práticas que emperram a concretização das finalidades almejadas pela Comissão Interamericana de Direitos Humanos.

Esse artigo é um desdobramento de uma pesquisa de mestrado, que partindo de questões mais amplas tentou aprofundar os estudos sobre o controle penal da pobreza no contexto urbano, problematizando as portas de entrada no cárcere (ROMÃO, 2019). A escolha metodológica de adotar as audiências de custódia como local da pesquisa de campo permitiu analisar o momento estratégico entre a prisão em flagrante e a produção da decisão de decretação de prisão cautelar ou restituição de liberdade, aproveitando o acesso ao corpus documental que é produzido no entorno deste ato judicial.

defensores públicos e juízes, os sujeitos que participam da audiência representando órgãos públicos que intervêm, de forma mais ou menos direta, na produção de documentos oficiais.

4 Ver os Relatórios Fim da Liberdade (IDDD, 2019), Audiência de custódia, prisão provisória e medidas cautelares: obstáculos institucionais e ideológicos à efetivação da liberdade como regra (CNJ, 2018) e Tortura Blindada (CONECTAS, 2017), além dos artigos de Camila Dias e Laís Kuller (2019), Carolina Ferreira (2017) e Yuri Teixeira (2019). 
Aqui pretende-se analisar como atores processuais se comportam no momento de debater e decidir sobre a aplicação de medidas quando estão diante de pessoas em situação de rua, seguindo a pista de Salo de Carvalho (2010a) que aponta o caminho metodológico de estudar grupos mais expostos ao encarceramento, a fim de analisar o potencial desencarcerador de medidas alternativas. Dessa forma, este artigo partiu da questão: como ocorre a aplicação de medidas cautelares nos encontros presenciais entre atores jurídicos e pessoas em situação de rua em audiências de custódia?

A pesquisa de campo foi realizada no Núcleo de Prisão em Flagrante e Audiências de Custódia de Salvador, em dois períodos do ano de 2018, a fim de garantir uma razoável heterogeneidade de casos, considerando que Salvador apresenta diferentes dinâmicas de circulação urbana e atuação das forças de ordem entre o verão e outras épocas do ano. A fim de obter um universo geral de dados, foram observadas 69 audiências de custódia, a fim de colher dados sobre uma dinâmica mais ampla em relação ao objeto da pesquisa. No que se refere ao universo de análise, foram estudados casos de 19 pessoas em situação de rua, com observação de audiências de custódia e análise documental dos 19 autos de prisão em flagrante e 52 processos pretéritos - entre ações penais e autos de prisão em flagrante -, que constavam como registros criminais.

Segundo a doutrina processual penal crítica, a oralidade processual provocaria um melhor conteúdo decisório (PRADO, 2005), ampliando e efetivando espaços de resistência ao criminalizado, com uma maior possibilidade de esclarecimento de fatos, individualização de condutas e resgaste de histórias de social dos sujeitos e do próprio contexto conflitivo. Através das audiências de custódia, onde supostamente a objetificação de um criminalizável deveria ser soterrada, a análise da aplicação de cautelares pessoais, nesta pesquisa, considera que o racismo também é produtor de uma racionalidade, que rege a constituição das ações, a normalização e a compreensão das relações (ALMEIDA, 2018).

Com a percepção de que o sistema de justiça penal é um mecanismo atravessado por relações sociorraciais, mobiliza-se a raça ${ }^{5}$ enquanto

5 Mbembe (2017) compreende a raça em sua dinâmica histórica e sócio-política (MUNANGA, 2003), uma vez mitigada a noção biologicista antes 
categoria de análise, vez que substantiva e complexifica não só o debate sobre a oralidade, mas o estudo da função social complexa da punição, em seu âmbito repressivo e "positivo" (FOUCAULT, 2014). Ao aprofundar a análise sobre a conformação dos discursos, das práticas punitivas e de seus efeitos (PIRES, 2017), a abordagem teórico-metodológica situa o controle da população de rua nos processos de criminalização antinegra da pobreza, uma vez que a experiência negra contemporânea está inserida na gramática da antinegritude, na qual sua posição estrutural na sociedade conforma o paradigma de humanidade e cidadania (VARGAS, 2017).

O trabalho apresenta o entendimento de promotores e juízes sobre medidas cautelares pessoais em espécie - cuja aplicabilidade prática é tradicionalmente ignorada enquanto objeto de pesquisa - compreendendo os ditos e os não ditos que permeiam os debates orais e os documentos escritos que culminam em uma decisão judicial, em busca de elementos que escapam das explicações tradicionais fornecidas pela sanção jurídico-formal (BATISTA, 2003ab). Com isso, foi possível ainda expandir a análise para além da mera ausência ou insuficiência de fundamentação, problematizando as funções não declaradas que vêm sendo atribuídas às medidas cautelares na gestão da circulação urbana e as dificuldades de se romper com a lógica da "prisão a médio prazo".

\section{ENTRE DEbates ORAIS E DECISÕES JUdiciaIs: ObSERVAÇÃo DE AUDIÊNCIAS DE CUSTÓDIA E ANÁLISE DE AUTOS DE PRISÃO EM FLAGRANTE}

Pesquisar no âmbito do judiciário, durante as suas práticas cotidianas, se justifica pelo interesse de tentar acessar a realidade como ela é, como fruto do próprio cuidado com os dados empíricos. Isso realça a importância do diálogo metodológico com pesquisas sobre aplicação do direito oriundas de outros campos. A antropóloga Mariza Peirano (2014)

encampada com um discurso que se pretendia cientificista - especialmente até meados do século XX. O filósofo também critica um pretenso "racismo sem raça”, no qual violências contemporâneas tentam se blindar do seu conteúdo discriminatório e hierarquizante, mas que na verdade representa um aprimoramento da discriminação (MBEMBE, 2017). 
destaca como a teoria é reinventada constantemente pelo contato com novos dados e novas experiências de campo.

Algumas vantagens metodológicas podem ser obtidas da antropologia do Estado, que acumulou reflexões metodológicas no curso dos estudos sobre aspectos da organização estatal, como processos eleitorais, cenas judiciais ou funcionamento de órgãos do Poder Judiciário, por exemplo (BEVILÁCQUA, 2001). Ao buscar observar atores jurídicos no exercício regular de suas funções, diante de uma pessoa recém-presa, a pesquisa lidou com o risco concreto de alteração das performances dos atores, caso interferissem na coleta de dados na observação, o que esterilizaria a própria análise.

Nas audiências de custódia do $\mathrm{NPF}^{6}$, em situações usuais, é frequente a circulação de outros pesquisadores, estudantes e profissionais das diversas instituições, jurídicas ou de assistência psicossocial, presentes naquele espaço. Além da dificuldade gerada por essa rotatividade, a coleta de dados nas audiências públicas seria profundamente prejudicada com a revelação da identidade de pesquisador a cada pessoa que circula nestas cenas específicas. Essa opção metodológica ampliou o olhar sobre a interação entre atores jurídicos e pessoas presas em flagrante, permitindo problematizar os momentos entre audiências e os atos informais que ocorrem à revelia do procedimento estabelecido pela Resolução 213/2015 do CNJ. Contudo, a adoção da técnica encoberta de coleta de dados nas audiências foi relativizada, já que se restringiu aos atores diretamente envolvidos com os momentos mais sensíveis de observação ${ }^{7}$.

Manuela Abath Valença e Marília Montenegro (2020) descrevem como a prática sequencial de atos judiciais, atravessadas por um

6 A Resolução 16 de 14 de agosto de 2019 do TJBA transformou o Núcleo de Prisão em Flagrante e Audiências de Custódia (NPF) em Vara de Audiência de Custódia, que fora instalada em 20.09.2019.

7 Apenas na minha primeira entrada na sala de audiência, fui conduzido por um servidor do judiciário, que me apresentou ao membro da magistratura em atividade naquele dia - que faz parte do total de quatro magistrados que se revezaram durante os dias em que estive no campo - momento em que apresentei rápida e suscintamente a pesquisa, de modo a preservar a viabilidade da técnica encoberta de coleta de dados. Em todos os dias ingressei simultaneamente a outros estudantes e profissionais das equipes de assistência jurídica ou psicossocial. 
ritmo acelerado, por um interesse em antecipar o fim do expediente e por metas a serem batidas, constituem um ambiente mais informal que propicia, a depender do caso, um tratamento jocoso com o crime praticado e as pessoas envolvidas no conflito que está por trás da prisão em flagrante. Naquela pesquisa fica evidente algo que também constatei em outra oportunidade (ROMÃO, 2019): a importância metodológica dos momentos de não gravação do ato judicial, a partir das frestas analíticas sobre as interações pessoais e suas verbalizações que não são registradas nos documentos processuais escritos.

A observação semiestruturada, ao permitir o acesso ao ocasional e acidental, lida com a espontaneidade das cenas que podem afetar uma pesquisa qualitativa, como apontam Marconi e Lakatos (2003). Por isso, foi uma técnica adequada para acessar os ditos e não ditos que circundam as audiências de custódia. A elaboração prévia de um formulário não rígido com quesitos destinados se destinou apenas a guiar a coleta de dados, que foi feita com o uso de um caderno de campo, no qual se inseria as informações, os relatos, as percepções e as frases dos sujeitos envolvidos na pesquisa. Em seguida, esse registro era transcrito de forma digitalizada para os formulários de encontros em audiências e para o arquivo de anotações gerais, no qual se produziu uma categorização dos achados da pesquisa.

Buscando o contato com uma heterogeneidade maior de casos e com sujeitos mais diversos, a pesquisa de campo foi dividida em dois períodos do ano de 2018, contemplando tanto o período marcado pelo auge das festas de rua que marcam a vivência na cidade - janeiro e março -, com impactos no comércio e na atuação das forças de ordem, quanto em um momento de maior retração em relação àquele - setembro e outubro. Em toda a pesquisa, observei audiências de custódia envolvendo 69 pessoas presas, 04 juízes, 03 defensores públicos, 03 promotores de justiça e advogados diversos ${ }^{8}$, a fim de trabalhar qualitativamente com amostras de

8 Em relação a representantes de profissões jurídicas, a flexão do gênero apresentada neste artigo não condiz necessariamente com a realidade, tendo em vista a estratégia de não facilitar possível identificação de quem foi objeto de observação. Assim, uma limitação do presente trabalho decorre de não ter aprofundado a atuação generificada na advocacia, promotoria ou 
um universo geral (PIRES, 2014), referente a todas pessoas que receberam medidas cautelares diversas ou foram presas preventivamente.

Os atores institucionais atuavam de forma constante e em revezamento, em uma baixa rotatividade, ${ }^{9}$ o que justifica a pouca quantidade desses sujeitos em um período razoável, em que as etapas de coleta se distanciam em seis meses. Para o objeto da pesquisa, isso permite uma interpretação sistemática da condução das audiências e da produção de decisões judiciais.

No que se refere à amostra operacional, enquanto uma determinada quantidade apta a esclarecer aspectos gerais das questões de pesquisa (PIRES, 2014), foram observadas audiências de custódia e analisados documentos processuais de 19 pessoas em situação de rua distintas conduzidas ao órgão judicial. Como o deslocamento no campo pretendia uma compreensão sobre o dentro e o fora das audiências de custódia, também foram observados atendimentos psicossociais do Programa Corra pro Abraço (PCPA), uma das instituições multiprofissionais que interagem com a Central Integrada de Alternativas Penais, prevista pela Resolução 213/2015 do CNJ.

Os atendimentos psicossociais eram realizados primordialmente após as audiências, contando com o apoio de servidores do judiciário e também da magistratura, que era provocada pelo Programa para priorizar a garantia de um acolhimento multiprofissional em vez do uso da prisão preventiva. A equipe multiprofissional tinha como público pessoas em situação de rua, com uso abusivo de drogas ou com necessidades referentes à saúde mental.

A proposta do Programa consistia ainda no esforço de evitar uma maior fragilização dos vínculos e o isolamento de algum assistido

magistratura durante a interação com pessoas presas e nos processos de tomada de decisão.

9 Também constatado por Daniel Fernandes e Elmir Duclerc (2020) e pelo Ministério da Justiça (2016). Atualmente, com a transformação do Núcleo de Prisão em Flagrante em Vara de Audiência de Custódia, com base na Resolução 16/2019 do Tribunal de Justiça, há uma concentração de funções da magistratura. Entre setembro e o início de 2020, atuou um juiz substituto e só posteriormente assumiu uma juíza titular. Ambos encontrar uma conformação sobre os modos de fazer que se desenhou entre 2015 e 2019. 
eventualmente preso, além de ser um articulador de rede de serviços que pudessem atender às suas demandas psicossociais. Isso contribuía para que o PCPA recebesse informações do cartório ou da assessoria dos defensores públicos sobre a existência de APFs referentes ao seu público, razão pela qual o Programa foi uma importante fonte de dados para esta pesquisa, ao facilitar a observação de audiências envolvendo pessoas em situação de rua.

Na primeira etapa de observação, entre janeiro e março de 2018, em um período de 24 dias úteis, compareci ao NPF em 14 dias úteis ${ }^{10} \mathrm{e}$ realizei observação de 7 ( 6 homens e 1 mulher) pessoas distintas que foram presas em situação de rua. Dentre essas 7, acompanhei o atendimento psicossocial de 6 delas ( 5 homens e 1 mulher) e observei audiências de custódia de 5 ( 4 homens e 1 mulher) delas. Em relação a 4 pessoas em situação de rua, foi possível assistir tanto as suas audiências de custódia quanto o seu atendimento psicossocial.

Na segunda fase de coleta de dados, entre setembro e outubro de 2018, dentre os 24 dias úteis do período, visitei o NPF em 18 dias úteis, observei 12 pessoas em situação de rua distintas (todos homens), entre 7 atendimentos psicossociais e 7 audiências. Em relação a 2 pessoas em situação de rua, pude observar tanto o atendimento psicossocial quanto a audiência de custódia. Em ambos os períodos, a retirada do campo se deu quando se percebeu a ausência do surgimento de novos fatos relevantes, em compasso com a necessidade de cumprir os prazos para finalizar a pesquisa.

Durante a pesquisa, as decisões judiciais eram realizadas majoritariamente pela forma escrita, sendo comum que a pessoa presa saísse da sala de audiência de custódia sem saber qual seria o seu destino, entre a liberdade e a prisão. A análise documental, junto à experiência da observação, exigiu uma maior atenção em relação aos vestígios e ao exercício do poder que pudessem "evidenciar o modo como as pessoas percebem elas mesmas e os outros, definindo-se e posicionando-se no

10 A primeira metade desses dias se refere ao período imediatamente anterior aos dias de carnaval, que por uma opção metodológica não entraram na pesquisa. A segunda metade se refere às duas semanas seguintes à festa de rua, quando já haviam sido retomadas as atividades ordinárias no órgão judicial, com a presença dos atores jurídicos alocados naquela unidade. 
espaço social" (OLIVEIRA; SILVA, 2005, p. 247). Esses documentos historicizam o passado recente e, entre seus silêncios e excessos, pode-se aprender mais sobre seus autores, especialmente através do que dizem sobre os "outros", atentando ao desafio de perceber os códigos do racismo que estão atravessados por discursos pretensamente neutros que conformam a dogmática jurídica e a atuação judiciária (BERTÚLIO, 1989; ALEXANDER, 2012).

Conforme André Cellard (2014), a pesquisa documental envolve enfrentar diversos obstáculos e armadilhas situados nos limites intrínsecos de uma fonte que representa vestígios da atividade humana, com atravessamentos políticos e sociais diversos. Uma pesquisa no presente, que pode observar um documento judicial sendo produzido na prática de atores jurídicos, ganha outra dimensão de análise, complexificando também os pareceres orais em audiências, que costumam ser reduzidos a termo de forma bastante sucinta e genérica nos autos de prisão em flagrante. Dessa forma, foi possível analisar a produção de silenciamentos e a mediação judicial na construção da narrativa em um documento histórico que é o processo (OLIVEIRA; SILVA, 2005). Em atenção ao que está oculto, nas entrelinhas, é que foi possível estudar o controle da pobreza urbana em Salvador, mediado pela aplicação de medidas cautelares alternativas e sua relação com a prisão.

No curso da pesquisa, foi importante considerar a relevância de problematizar questões que decorrem da presença de um debate sobre a reiteração delitiva, algo verificado em diversos estados (CNJ, 2018) e que acaba constituindo uma das variáveis jurídicas mais importantes para a decretação de prisão preventiva (LAGES; RIBEIRO, 2019). Por conta disso também foram analisados registros criminais anteriores, produzidos entre 2013 e 2018, referenciados nos APFs e que se relacionavam às pessoas em situação de rua ${ }^{11}$. O acesso a estes e aos demais documentos,

11 O limite temporal de cinco anos foi estabelecido para garantir a viabilidade da coleta e análise, evitando se distanciar do contexto presente do controle urbano em Salvador, tomando como parâmetro o prazo relativo aos efeitos da reincidência. Essa coleta foi importante, considerando que entre as 19 pessoas presas em situação de rua, 14 já tinham sido presas anteriormente. Além dos $19 \mathrm{APFs}$ recém-chegados ao NPF, analisei 52 processos anteriores à nova prisão. O acesso a estes documentos, sem restrições de sigilo, se deu através de consulta processual no portal eletrônico do Tribunal de Justiça da Bahia. 
sem restrições de sigilo, se deu através de consulta processual no portal eletrônico do Tribunal de Justiça da Bahia. Essa coleta foi importante considerando que entre as 19 pessoas presas em situação de rua, 14 já tinham sido presas anteriormente.

Esse foi o quadro metodológico que permitiu a análise do processo de aplicação de medidas cautelares pessoais pelos atores processuais em audiências de custódia, entre pareceres orais e decisões escritas. A interseção de técnicas metodológicas, cruzando dados da observação com dados da análise documental contribuiu para, dentro das limitações de uma pesquisa qualitativa (CRESSWELL, 2014), apresentar uma generalização teórico-analítica sobre discursos e práticas na gestão de mecanismos punitivos que constituem parte do controle urbano que é mediado pelo judiciário.

\section{AlÉm da Soltura: PENSANdo as medidas CaUtelares diversas APÓS A IMPLEMENTAÇÃO DAS AUDIÊNCIAS DE CUSTÓDIA}

No contexto em que a ADPF 347 foi julgada procedente pelo STF, em 2015, reconhecendo o "estado de coisas inconstitucional" do sistema carcerário brasileiro, em razão de uma violação sistemática de direitos fundamentais derivada do que a criminologia denomina de era do grande encarceramento brasileiro, o CNJ, através de atos e políticas institucionais, estimulou a adoção de alternativas penais. Além de elaborar resoluções regulamentando a justiça restaurativa e as audiências de custódia, realizou dois Fóruns Nacionais de Alternativas Penais (FONAPE), em 2014 e em 2016. Neste último, que aconteceu na cidade de Salvador, o presidente da Comissão Interamericana de Direitos Humanos, James Cavallaro, ressaltou a importância das audiências de custódia e destacou a necessidade de enfrentar o uso desnecessário da prisão preventiva na grave realidade carcerária brasileira, alertando que naquela data o país tinha um número de presos cautelares maior que o total de presos em $1995^{12}$.

12 Como resultado deste evento, foi a elaborada a Carta de Salvador, que traz entre os resultados: “[...] Item 2. Propor ao CNJ a reformulação e o fortalecimento da política judiciária para as alternativas penais, prevista na Resolução $n^{0} 101 / 2009$, alinhando-a com o futuro projeto do Sistema Nacional de 
O então presidente do CNJ, ministro Ricardo Lewandowski, assinou uma carta de intenções com a Comissão Interamericana de Direitos Humanos (CIDH) para fortalecer uma mentalidade do judiciário compromissada com os direitos humanos. Na ocasião, também influenciou o órgão brasileiro para que editasse as Regras de Tóquio elaboradas pela ONU em 1990, que orientam a elaboração de medidas não privativas de liberdade.

A doutrina processual penal visualiza as audiências de custódia como o instrumento de garantia de direitos fundamentais, especialmente por possibilitar que se evitasse descabidas decretações de prisão preventiva e por abrir espaço de oralidade para um debate acerca da real necessidade de aplicação de medidas cautelares diversas, com participação de todos os sujeitos processuais envolvidos (SOARES, 2018).

Um ano antes da implementação desse instituto processual, enquanto o Brasil registrava $41 \%$ de presos sem condenação, na Bahia esse percentual chegava a 64\% (DEPEN, 2016). Segundo dados mais recentes à época da coleta de dados para esta pesquisa, a Bahia seguia como um dos estados com maior percentual de presos sem condenação, com 58\%, dividindo a quinta posição com Minas Gerais (DEPEN, 2017) ${ }^{13}$.

Tanto em documentos de pesquisas institucionais e eventos acadêmicos quanto nos diálogos cotidianos entre quem circula no judiciário e no sistema prisional, tem sido mencionado que a implementação das audiências de custódia, em 2015, pode estar relacionada a uma redução percentual da prisão preventiva para homens e mulheres, conforme dados

Alternativas Penais - SINAPE. Item 3. Reconhecer o êxito da política judiciária de audiências de custódia para fins de redução do encarceramento provisório e proteção dos direitos e garantias fundamentais, e esclarecer à sociedade os seus reais objetivos, que não se confundem com a liberação indiscriminada de pessoas em conflito com a lei". (grifamos)

13 Entre 2019 e junho de 2020, nota-se ausência de relatórios periódicos do Departamento Penitenciário Nacional, que unifica os dados dos estados brasileiros. Tomando como parâmetro a divulgação periódica de dados pela Secretaria de Administração Penitenciária (SEAP), sobre a ocupação das unidades prisionais masculinas e femininas do estado da Bahia, verifica-se que esse percentual orbitava a marca dos $46 \%$, em 17 de março de 2020, algo que ainda se verifica em 08 de junho de 2020, mesmo após a Recomendação 62 do CNJ frente à pandemia de coronavírus. 
do $\mathrm{CNJ}^{14}$, do Departamento Penitenciário Nacional (2014, 2016, 2017, 2018 e 2019) e da Secretaria de Administração Penitenciária da Bahia (SEAP). Conforme dados da Defensoria Pública (2019), entre 2015 e 2018, a taxa de decretação de concessão de liberdade provisória para homens e mulheres, nas audiências de custódia em Salvador, foi de 51\%. Contudo, o mesmo relatório destaca que apenas $4,8 \%$ de todas as pessoas que foram conduzidas ao Núcleo de Prisão em Flagrante, hoje transformado em Vara de Audiência de Custódia, receberam liberdade sem qualquer restrição.

É preciso aprofundar o olhar sobre os dados da prática judiciária nas audiências de custódia, sem perder de vista a realidade carcerária das unidades prisionais, a fim de não cair em uma mistificação dos números que camuflem o concreto e persistente sofrimento que decorre diretamente da atuação do poder judiciário. Uma análise mais efetiva das audiências de custódia fica prejudicada por não haver uma sistematização satisfatória de dados do período anterior ao qual elas foram implementadas, o que dificulta saber exatamente quais foram as mudanças na atuação dos órgãos jurídicos em relação à decretação de prisão preventiva.

Em todo caso, pode-se afirmar que a manutenção de uma média de mais da metade - $57 \%$ - de presas sem condenação, para as mulheres, e $48 \%$, para os homens em julho de $2020^{15}$, nos dá mais um sinal de que não há uma redução expressiva no uso da prisão preventiva, Salvador, mesmo que possa ter havido uma redução quantitativa do percentual de decretação de prisão cautelar em audiências de custódia.

Ademais, é preciso pensar a redução da lógica carcerária para além da diminuição da aplicação da prisão preventiva, considerada isoladamente. A Lei 12.403/2011 entrou em vigor com a promessa de tornar a liberdade a regra no processo penal. As medidas cautelares diversas da prisão, ou

14 Disponível em: https://paineis.cnj.jus.br/QvAJAXZfc/opendoc.htm?document=qvw_1\%2FPainelCNJ. qvw\&host=QVS\%40neodimio03\&anonymous=true\&sheet=shSISTAC. Acesso em 11.03.2020.

15 Os dados são referentes ao relatório do dia 14.07.2020 da Secretaria de Administração Penitenciária da Bahia, tendo sido desconsiderados os números sobre medida de segurança, por não haver detalhamento da natureza cautelar. Disponível em: http://www.seap.ba.gov.br/sites/default/ files/dados/2020-07/PRESOS\%20CONDENADOS\%20E\%20PROVIS\%C3\%93RIOS\%20-\%2014-07-2020.pdf 
medidas cautelares pessoais, foram ampliadas em um rol extenso no art. 319 do $\mathrm{CPP}^{16}$ para serem alternativas à decretação de prisão preventiva.

Entretanto, a dificuldade de romper a densa cultura inquisitória do Ministério Público e do judiciário (CARVALHO, 2010b) mantém altos níveis de encarceramento cautelar no país. A prática judiciária inverteu largamente esta finalidade aplicando as medidas em alternativa à própria liberdade. Pessoas, que antes teriam condições de ter liberdade plena durante a investigação ou o processo, agora ficam obrigadas a cumprir medidas que restringem direitos e liberdades, como circular livremente, transitar entre municípios, frequentar eventos culturais nas ruas, na hora que quiser, e não ser rastreado eletronicamente ou confinado em casa.

Ao investigar a potencialidade de redução de impacto carcerário das medidas desencarceradoras, no contexto de penas alternativas, Salo de Carvalho (2010a, p. 373) problematizou os entraves à superação efetiva da lógica prisional. Segundo o autor, a expansão as propostas de alternativas penais deve ser objeto privilegiado de um "debate responsável sobre os níveis de encarceramento e os efeitos amplificadores dos substitutivos penais", e acrescenta, "sobretudo se o objetivo é diminuir os enormes danos que o encarceramento em massa tem produzido, em termos de custos de vidas humanas, no Brasil”. Afinal, o uso crescente de alternativas penais foi contemporâneo às alterações legislativas que enrijeceram o cumprimento de pena e expandiram a prisão cautelar, facilitando a entrada e dificultando a saída do sistema carcerário, a partir dos anos 1990, década que tem a Lei de Crimes Hediondos como um marco na expansão sem precedentes da populacional prisional nas décadas seguintes ${ }^{17}$ (CARVALHO, 2010a).

A inversão ideológica das finalidades de direitos humanos e as possibilidades de mistificação e equívoco na constituição de alternativas concretas à prisão, trabalhadas exaustivamente pela crítica criminológica, demandam, ainda, não se desviar de um olhar sobre as consequências

16 Outras legislações penais especiais trazem medidas específicas, como é o caso da Lei Maria da Penha e as medidas protetivas.

17 Entre 1990 e 2014, esse acréscimo foi de 575\% (DEPEN, 2016). Isso se manifestou de forma ainda mais gravosa às mulheres, entre as quais houve um crescimento $656 \%$ entre 2000 e 2016 contra $293 \%$, entre os homens, no mesmo período (DEPEN, 2018). 
dessas medidas (COHEN, 1979). Mesmo bem-intencionadas, podem levar a mais repressão e coerção, na atualização neoliberal da gestão da vida negra em liberdade.

\section{ATORES JURÍDICOS NA GESTÃo DE MEDIDAS CAUTELARES ESPECÍ́FICAS E A LÓGICA DA "PRISÃo A MÉdIO PRAZO"}

No livro "Vigiar e Punir", embora não seja o principal objetivo de sua análise, Michel Foucault (2014) deixa pistas sobre o papel de mediação do judiciário no que ele chama de "sistema polícia-prisão". Ao analisar como a vigilância se expande para fora dos muros da prisão, o autor vai nos informar que essa instância é decisiva para o manejo da delinquência, em um controle diferencial das ilegalidades. Embora tenha contato com uma parcela ínfima do poder punitivo filtrada pelas agências policiais (ZAFFARONI, 1991), o judiciário, sem pisar nas ruas, vai ter uma função no controle da circulação de pessoas. É o que se vê na conformação de "perfis criminais", na definição de quais ações vão ser selecionadas para prosseguir o percurso de criminalização ou na produção de distintas respostas punitivas ao que foi carimbado como crime.

A partir da relevância do papel exercido pelos juízes no âmbito do controle jurídico-penal, como também situa Roberto Bergalli (2015), que passo a apresentar algumas reflexões das práticas em audiências de custódia que dialogam com as decisões proferidas por escrito, especialmente no que se refere aos "modos de fazer" relacionados à aplicação de medidas cautelares pessoais. A relevância metodológica da instância judicial, contudo, não restringiu o olhar à magistratura, mas aos demais atores institucionais que se fazem presente naquela cena jurídica - promotoria e defesa técnica - e além de contribuir para o conteúdo decisório, complexificam o olhar sobre os silêncios e os ditos da narrativa processual (OLIVEIRA; SILVA, 2005).

\subsection{Os SENTIDOS DAS MEDIDAS CAUTELARES PESSOAIS NAS INTERAÇÕES EM AUDIÊNCIAS DE CUSTÓDIA: O QUE ESCAPA DOS REGISTROS OFICIAIS}

Nas audiências de custódia observadas em Salvador, o entendimento dos atores processuais sobre as medidas cautelares pessoais 
pode ser notado em três situações ligadas ao momento de análise sobre a decretação ou não de uma prisão cautelar. Na primeira, fundamenta-se a continuidade da prisão sem mencionar o porquê de medidas menos gravosas não poderem ser utilizadas. Ou seja, há uma ausência completa de fundamentação sobre a liberdade plena. Na segunda, os atores simplesmente dizem, sem justificar e de forma genérica, que as medidas alternativas não são suficientes para o caso e partem para os argumentos selecionados para justificar a necessidade da manutenção da custódia (reiteração, periculosidade, ordem pública etc.). Na terceira, essas cautelares são um argumento autônomo na análise do cabimento e da necessidade da prisão preventiva.

"As medidas cautelares diversas da prisão revelaram-se ineficazes". Esta frase se faz presente de forma recorrente nos pareceres orais do Ministério Público e são reproduzidas, com alta frequência, nas decisões judiciais escritas, para concluir que o cárcere é o destino que não se pode evitar. Como a reiteração criminosa demonstra o "fracasso" das alternativas penais, entre aqueles que tiveram a liberdade concedida em outro momento, é o suposto "sucesso" da lógica prisional que vai superar aquele fracasso ao conter o sujeito, em que pese o sucesso concreto do cárcere seja a produção da reiteração delitiva ou da reincidência (FOUCAULT, 2014).

O abandono da cautelaridade - cuja finalidade é de garantia da viabilidade de um processo penal, na tutela da instrução, para não prejudicar a colheita de provas, ou na aplicação de eventual pena, para impedir um risco concreto de fuga - também atinge a aplicação das cautelares diversas da prisão. Por via indireta, tem-se uma expectativa entre promotores e juízes que as cautelares alternativas cumpram uma espécie de prevenção especial negativa, que evite a prática de novos crimes, expandindo o conteúdo do texto legal do já citado do art. 282, inciso I, do CPP. Essa intenção se mostra de forma generalizada às espécies de medidas.

A cena do "paredão"18 é fundamental para entender como as medidas cautelares são vistas pelos atores institucionais. Na segunda

18 Em Salvador, os atores jurídicos adotaram, pelo menos até o segundo semestre de 2019, esta prática para os casos em que vislumbram uma possível restituição da liberdade sem maior análise. A partir de um filtro prévio realizado 
etapa do campo, notei que as audiências demoravam muito para começar, mesmo com os atores processuais presentes no NPF. O que ocorria era um bloco de "audiências informais", os "paredões", para depois, em outro bloco, começarem as audiências de custódia, sob o rito formal - seguindo uma ordem de intervenções dos atores, de questionamentos e com a gravação audiovisual do ato e a elaboração de um Termo de Audiência que é juntado no APF.

No caso da cena do "paredão" em Salvador, faz-se uma análise preliminar dos APFs da pauta de audiências, selecionando aqueles que se referem a crimes sem violência física ou arma de fogo, como receptação, tráfico de drogas (quando pouca a quantidade de drogas, a partir de critérios subjetivos dos atores processuais), furto e ameaça. Ou seja, aqueles em que se entendia que a restituição da liberdade não demandaria uma maior análise. Pelos critérios de seleção, as pessoas em situação de rua têm chance razoável de vivenciar isso, já que furto, receptação e tráfico de drogas são tipos penais que vêm muito a calhar na exposição acentuada desse grupo à prisão. Das 11 pessoas em situação de rua que foram recolocadas em liberdade, 05 foram ouvidas em "paredão" quando conduzidas presas ao NPF.

Reduz-se a potencialidade das audiências de custódia, abandonando o objetivo de prevenção à tortura e maus tratos, enquanto se consagra a finalidade de decisão entre liberdade e prisão, sem que se fuja ao binômio que tende a condicionar essa liberdade em quase todos os casos. As decisões decorrentes dos paredões, em regra, homologam a prisão e aplicam medidas cautelares diversas, sem que se debata a legalidade da prisão e a proporcionalidade e necessidade das medidas cautelares (inclusive fiança a pessoas em situação de rua). Com isso, desvirtua-se o escopo garantidor da necessidade do contato presencial que, enquanto

sobretudo pelo Ministério Público e pelo judiciário, realizava-se um "acordo", onde se vê uma participação reduzida ou suprimida da defesa, de um lado, e um protagonismo do Ministério Público, de outro. Como não há registro e nem oitivas padronizadas e gravadas, o sinal é verde para lições de moral e esporros de toda sorte, perguntas invasivas e desconectadas com o fato, muitas vezes com o intuito de traçar o perfil criminoso da pessoa presa. Luan Rosário (2018) e o IDDD (2019) também registraram a ocorrência desse ato informal no mesmo ambiente judicial. 
elemento humanizador da fase processual, objetiva a construção de uma decisão mais adequada (CORDEIRO; COUTINHO, 2018).

Essa forma de tomada de decisão supostamente negociada, em prol da liberdade, não nos leva a comemorar o inverso de uma condenação drive-thru em mesa de audiência. ${ }^{19}$ A dinâmica própria em torno dos debates sobre a aplicação dessas medidas cautelares diversas consolidou a importância de estudá-las enquanto pena antecipada, na expansão do controle a céu aberto (AUGUSTO, 2010), que, longe de suplantar o encarceramento, se soma a ele. A preocupação acerca do grau de restrição de liberdade e das funções não declaradas que podem fazer de uma medida cautelar uma pena soft, é negociada, nem sempre entre acusação e defesa, mas entre acusação e judiciário ou entre a acusação e ela mesma, já que era recorrente a ausência da Defensoria Pública e, por vezes, do próprio judiciário, em muitos destes atos informais. Stanley Cohen (1979) oferece uma lente criminológica para entender que a suavidade do sistema pode ser mais aparente que real, mascarando intenções coercitivas e as suas consequências.

Com o passar dos dias, o filtro de seleção dos APFs para selecionar quem deve passar pelo "paredão" nem sempre ocorria previamente e, às vezes, entre uma audiência formal e outra, os atores processuais decidiam que tal caso podia ter a análise abreviada via "paredão". Assim, parte dos expectadores das audiências acabavam assistindo alguns desses procedimentos informais, de modo que o ato se tornou mais corriqueiro, ainda que houvesse uma frequência e intensidade distinta, a depender dos atores processuais envolvidos.

A defesa técnica, acossada no contexto do grande encarceramento e dos apelos punitivos que aproximam o judiciário da "segurança pública", tem como grande objetivo evitar a prisão a qualquer custo, diante das violências no cárcere brasileiro. As alternativas ao cárcere são utilizadas

19 Algo já ensaiado na prática judiciária brasileira. Em uma audiência de custódia no Acre não se viu uma aplicação de pena negociada, em tese, mas um julgamento sumário, em que a denúncia foi oferecida pelo Ministério Público, a defesa preliminar apresentada pelo advogado e a condenação foi decidida, tudo em minutos. Disponível em https://www.jota.info/justica/justica-acre-condena-reu-em-tres-dias-apos-prisao-em-flagrante-29072016. Acesso em 13.12.2018. 
por ela como redução de danos, ainda que estejam restringindo direitos de quem teria plenas condições de responder a uma imputação em liberdade. Na correlação de forças, restrições outras à liberdade podem ser aplicadas com uma renúncia parcial dos direitos ao contraditório e à ampla defesa.

Para os juízes, as cautelares podem assumir uma aparência de benesse, uma "chance" caridosamente concedida por eles a quem poderiam ter enviado maldosamente para uma unidade prisional. Isso pode ser manejado sem qualquer função declarada às alternativas, ou como uma "quase-prisão" ou com a aplicação de várias medidas com intenções retributivistas e até com ideias correcionalistas. Luís Carlos Valois (2015) critica como atores jurídicos transformam direitos em "benefícios", o que inverte a gramática e modifica a relação perante aqueles que preenchem as condições para exigir um direito, que não pode ser negado uma vez presentes os requisitos legais.

A ideia de que poderiam ter enviado à prisão pressupõe um exercício de poder com a imensa arbitrariedade que ele pode conter, especialmente no cotidiano da atuação judiciária que lida com os sujeitos situados na zona do não-ser ${ }^{20}$, para quem a prisão é sempre uma possibilidade. João Vargas (2017) avança nessa discussão teórica discutindo como a antinegritude produz uma violência estrutural que mantém o desrespeito à vida e à liberdade negra, independentemente dos avanços de cidadania, como as garantias individuais tributárias do liberalismo. Embora fundamentais para buscar limitar o poder, elas esbarram na desumanização que conforma a noção de sujeito de direitos.

O contato presencial entre juízes, promotores e pessoas presas também pode reforçar uma postura de autoridade desregrada que se exerce negando ou concedendo um prêmio ou um favor, em vez de garantir o direito à liberdade ou decidir pela prisão apenas sob critérios objetivos e

20 Fanon (2008) trabalhou como o racismo e a racialização do mundo produziram a interdição do sujeito, vez que o negro é aquilo que "não é", ou seja, habita uma zona do não-ser, de desumanização, que constitui a zona do ser, habitada por não negros, com pleno respeito de sua condição humana. O amplo campo de violações possíveis - alheio aos avanços mais básicos de garantia formal de direitos - a pessoas passíveis de serem vinculadas ao rótulo de bandido segue esse percurso de hierarquização sociorracial fruto da cisão provocada pelo colonialismo entre o portador de um mal e o portador de atributos humanos. 
legais. Em uma audiência que observei na primeira etapa do campo, um promotor de justiça requereu diversas cautelares, sem proporcionalidade, por achar que dois guardadores de carro, negros, a serviço da prefeitura, detidos com cartelas falsas de estacionamento, estavam muito "abusados" na cidade. Juízes e juízas, ao concederem a "chance” de responder em liberdade, deixavam claro a discricionariedade ao julgar, como foi exposto em outra audiência: "não quero mais ver você aqui. Se aparecer aqui é prisão preventiva", reforçando o peso negativo apriorístico que atribuem a uma nova detenção, que ignora prisões ilegais e abusos de poder ${ }^{21}$.

No segundo período de campo, a inclinação para se requerer ou decretar mais medidas cautelares ou medidas mais restritivas se pautava pelos registros anteriores. Quando foi possível observar alguma proporcionalidade na aplicação das cautelares a quem já respondia a outros processos, o recolhimento noturno - muitas vezes com forte carga moralista - e o monitoramento eletrônico eram vistos como uma alternativa à prisão preventiva, em que pese não houvesse fundamentação específica para cada uma das medidas. A cautelar era imposta como medida de castigo, como uma sanção antecipada quando se estava diante alguém que se entendesse merecedor de uma retribuição imediata.

Seguindo o padrão generalizado na prática judiciária, diante do silêncio do CPP, a duração das medidas é incerta ${ }^{22}$, e, no caso do recolhimento domiciliar noturno, muitas vezes era ignorado se a pessoa tinha trabalho fixo ou qual o seu horário de trabalho, algo exigido pelo artigo 319, inciso $\mathrm{V}$, do CPP, a fim de que se possa restringir os dias de folga. O viés disciplinante da punição de reduzir a vida ao deslocamento trabalho-casa,

21 Manuela Valença e Marília Montenegro (2020), analisando cenas de audiências de custódia nas cidades de Recife e Olinda e as limitações desse instituto para lidar com casos de violência doméstica contra a mulher, também expõem situações de ameaça de uso da prisão preventiva contra o flagranteado ou de desconsideração com a vítima.

22 No período de realização da pesquisa, ainda não havia sido sancionada a Lei 13.964/2019, que passou a prever, no art. 316, § único, o prazo de 90 dias para revisão da necessidade de manutenção da prisão preventiva pelo órgão emissor da decisão. Ainda que entendamos que este prazo deve ser aplicado também às medidas cautelares menos graves, ele não se confunde com a definição de um prazo limite para duração de medidas cautelares em geral, tal como ocorre com a prisão temporária prevista na Lei 7.960/1989, a qual prevê uma sanção legal para o caso de inobservância do limite temporal. 
era assim atravessado pelo efeito desejado de mera contenção, de provocar uma "quase-prisão" em casa - especialmente quando junto à limitação de fim de semana e proibição de frequência determinados lugares, sendo que estas últimas, além de cautelares, também figuram como penas estabelecidas em lei, conforme os artigos 43, 47 e 48 do Código Penal.

\subsection{O CONTROLE DA CIRCULAÇÃO MEDIADO PELO JUDICIÁRIO: ALGUMAS PISTAS A PARTIR DA APLICAÇÃO DA CAUTELAR DE "PROIBIÇÃO DE ACESSO OU FREQUÊNCIA A DETERMINAdOS LUGARES" NO VERÃo dE SALVADOR}

Durante o verão, na primeira etapa do campo, a postura inquisidora de promotores e juízes esteva diretamente relacionada a um controle associado às festas populares ou de largo, que marcam decisivamente a vivência na cidade, e ao carnaval. Havia um consenso sobre aplicar o que chamavam de "todas" as cautelares, quando não se prendia. Normalmente, era um "pacote" entre quatro e seis, se houvesse fiança: apresentação bimensal em juízo para informar e justificar atividades e ser intimado de eventual ato do processo; proibição de ausentar-se da Comarca; proibição de frequentar festas populares; limitação de fim de semana; e recolhimento domiciliar noturno das $22 \mathrm{~h}$ às $6 \mathrm{~h}$.

Isso não significou uma redução do uso da prisão preventiva. Houve uma tendência maior também de manter as pessoas encarceradas, com os mesmos juízes atuando nas duas etapas da pesquisa. Em relação à população de rua, o número de pessoas mantidas presas, dentro do universo de análise, caiu de 71\%, para 25\%, na segunda etapa da pesquisa. Não há diferenças significativas, nos dois períodos, em relação aos dados sobre registros criminais anteriores e os crimes cometidos, tendo se mantido o protagonismo do furto.

Pessoas presas nos bairros Itapuã, na Liberdade ou na Pituba, distantes entre si; vendedores ambulantes, motoristas, atendentes, mecânicos ou desempregados; crimes de tráfico, furto, estelionato ou roubo; flagrantes ilegais ou legais; prisões com emprego ou não de tortura. A firmeza de uma postura diferenciada dos atores processuais no verão independe do que levou as pessoas ao NPF, das circunstâncias e do local da sua prisão, bem como da sua circulação na cidade - onde se fixam territorialmente ou trabalham. A aplicação abusiva de cautelares ou prisão 
preventiva teve em comum a criminalização de jovens negros e pobres. As festas de largo ou festas populares, como são conhecidas diversas celebrações pagãs, religiosas ou profanas, como o carnaval, a Segunda Gorda da Ribeira, a Lavagem do Senhor do Bonfim e a Festa de Iemanjá, ocorriam em locais muito distantes do território em que se deu a prisão da maior parte dessas pessoas.

A Lei 12.403/2011 fala em "proibição de acesso ou frequência a determinados lugares quando, por circunstâncias relacionadas ao fato, deva o indiciado ou acusado permanecer distante desses locais, para evitar o risco de novas infrações”. Essa cautelar estabelece o fim de evitar novas infrações, repetindo um requisito de constitucionalidade duvidosa do inciso I do art. 282 do CPP, ${ }^{23}$ vinculando-o ao controle em um território que deve estar ligado ao fato criminoso supostamente praticado.

Dentro de uma perspectiva metodológica que desnaturaliza os elementos jurídicos, é necessário compreender, por trás das aparências de cada evento, a complexidade sociorracial urbana e as dinâmicas entre o local e a totalidade, como propõe metodologicamente a criminologia crítica (MELOSSI, 2012), bem como perceber como alguns dispositivos e instrumentos jurídicos - ainda que colocados como neutros - desenvolvem uma função de marcadores de espaço (MBEMBE, 2017). A utilização dessa medida cautelar para funções ocultas pode ser uma pista para expandir horizontes para além de uma análise dogmática autorreferenciada, revelando como mecanismos de controle se relacionam com a produção de territorialidades urbanas (ROMÃO, 2019).

O filósofo camaronês Achille Mbembe compreende o controle da circulação inserindo a raça como uma categoria de análise no estudo foucaultiano sobre a era da segurança, voltando-se para a conjuntura do século XXI, explicando que "os processos de racialização têm como objetivo marcar estes grupos de populações, fixar o mais possível os limites nos quais podem circular, determinar exatamente os espaços que podem ocupar" (MEBEMBE, 2017, p. 71). Trata-se, segundo o autor, de um

23 “Art. 282. As medidas cautelares previstas neste Título deverão ser aplicadas observando-se a: I - necessidade para aplicação da lei penal, para a investigação ou a instrução criminal e, nos casos expressamente previstos, para evitar a prática de infrações penais". 
controle medido de circulação em nome de uma idealizada segurança geral, no qual o racismo produz o diferente e o situa para fora da zona do ser.

A sobrerrepresentação negra também está na situação de rua. No censo nacional realizado pelo Governo Federal, em 2008, 64\% eram negros. Em Salvador, segundo estudo do Projeto Axé de 2017, esse número vai a $88 \%$. É necessário destacar que, segundo o IBGE, os negros são $75 \%$ dos mais pobres e apenas $17 \%$ dos mais ricos no país ${ }^{24}$. Entre a produção neoliberal da miséria e o direito à cidade - toma-se a estatística para além de um retrato. Situar o controle da circulação em um estudo crítico ao funcionamento das agências do sistema penal envolve considerar a construção da negação enquanto sujeito a corpos negros, a fim de compreender dinâmicas de um controle penal tão diferenciado.

A interpretação de "determinados lugares" como "festas populares, bares, prostíbulos, bocas de fumo e casa de jogos de azar" - mencionadas em atacado em algumas decisões - se aproveita de uma persistente tradição moralista, que se alia à demanda por ordem atual de controle da densidade urbana e gestão da circulação negra. Especialmente quando não se procede a avaliação prévia da liberdade plena nem de requisitos centrais como a relação com o fato, ocorrência de flagrante forjado e relatos de torturas, como observado. Isso deve servir de alerta para aguçar criticamente a discussão sobre a possibilidade de uma interpretação extensiva no momento de aplicação de medidas cautelares pessoais (CASTRO, 2017). O contato com a atuação empírica dos atores jurídicos e o entrelaçamento entre saberes processual penal e criminológico pode contribuir decisivamente.

A prisão anterior, independente das suas circunstâncias, parece dialogar com os efeitos não meramente repressivos do registro ou das "passagens" na rua, que instrumentalizam uma segregação. Em uma audiência no mesmo período, disse um promotor para um rapaz negro que, apesar de "reiterar", receberia uma liberdade condicionada: "É quase prisão, viu? Prisão em casa. Parece liberdade, mas não é. Não vai ter ninguém filmando, mas você vai ser abordado (na rua). Vão perguntar se você tem passagem... E se você mentir... Sabe que é pior...”. A oralidade

24 Disponível em: https://biblioteca.ibge.gov.br/visualizacao/livros/liv98965. pdf. Acesso em 29.11.2018. 
no procedimento informal do "paredão" explicita o que os códigos da linguagem jurídica pretendem blindar. Para dificultar, reduzir, separar a "boa" da "má circulação" (FOUCAULT, 2008), a lógica do "recinto fechado" de que fala Mbembe (2017), ao delimitar os espaços pelo racismo, desterritorializa se encobrindo como uma benesse de liberdade.

O judiciário, no campo criminal, costuma ter uma relação de indiferença perversa com o lugar da população em situação de rua. Nos termos da geografia de Milton Santos (2014), talvez seja uma indiferença com o lugar e um intenso interesse pelo território. A declaração comprovada - em juízo - de ter residência fixa em algum território da cidade é condição elementar de cidadania, seja para um tratamento mais humanizado, seja para a efetivação de direitos no campo do processo penal.

A intensidade desta constatação se demonstra no fato de a Defensoria Pública ter tido que tecer uma estratégia, no Núcleo de Prisão em Flagrante, de não revelar a situação de rua de alguns de seus assistidos durante as audiências, uma vez que ela por si só tem se configurado como um risco concreto de manutenção da prisão. Isso levou a aplicação do recolhimento noturno domiciliar em um caso.

Em outros dois casos, mesmo os juízes reconhecendo as condições de vida na rua e restituindo a liberdade, essa medida apareceu, não se sabe se intencionalmente, por automatismo ou por reprodução de uma decisão pré-moldada. Em uma dessas audiências, o promotor chegou a cogitar o requerimento dessa cautelar. Dois homens em situação de rua haviam sido presos por roubo. Ao que respondia ação penal por tráfico de drogas, o ator processual pediu prisão. Ao que estava sendo preso pela primeira vez, ele pretendia pedir uma medida em liberdade mais gravosa, mas desistiu em tom de lamento: "recolhimento... não dá nem pra pedir porque ele mora na rua”. Mesmo assim, o juiz aplicou a medida na decisão escrita, sem sequer especificar o horário, que normalmente é fixado entre $22 \mathrm{~h}$ e $06 \mathrm{~h}$.

O monitoramento eletrônico surgiu de forma mais intensa na segunda etapa do campo, quando se fez mais presente nos debates dos atores processuais e nas falas das equipes psicossociais e servidores do cartório. Em outubro, após avaliar o caso de um assistido como de difícil soltura, pelo crime e pelo perfil dos demais atores processuais, um dos representantes da DPE-BA perguntou a um dos juízes se já tinha aplicado 
monitoramento eletrônico para quem vive na rua e se entendia cabível aplicá-lo. Recebeu uma resposta negativa: "Como que vai monitorar se não tem endereço?”.

A perspectiva causal-explicativa, a desumanização dos sujeitos e a desconsideração sobre as histórias de vida, que predominam na sala de audiência, afetam a própria atuação da DPE-BA. A tentativa de atuação de redução de danos para evitar a prisão leva a considerar opções que aumentam a exposição a violências de controle formal e informal, através de um instrumento que no Brasil bebe de uma histórica naturalização da subjugação dos corpos negros (PIRES, 2015).

\subsection{ENTRE a APLICAÇÃo AUTOMATIZADA E A "INSUfICIÊNCIA DAS MEDIDAS CAUTELARES": a RELEGITIMAÇÃo do CÁRCERE NA LóGICA dA "PRISÃo a MÉdIO PRAZO"}

Uma pesquisa do CNJ (2018), envolvendo cinco estados ${ }^{25}$ e o Distrito Federal, destacou que as medidas cautelares diversas mais aplicadas dizem respeito à facilitação da localização dos acusados pela justiça na continuidade do processo, como o comparecimento periódico em cartório para informar e justificar atividades e a proibição de se ausentar da comarca. De um total de 716 cautelares aplicadas nas audiências observadas, a mais frequente foi a de comparecimento periódico em juízo $(34,4 \%)$, mesmo que não se apresentasse algum indício concreto de que a liberdade poderia acarretar fuga ou outra obstrução da justiça. Em Salvador, entre os anos de 2017 e 2018, segundo o Relatório da Defensoria Pública do Estado da Bahia (2019), esse percentual é de 48,7\%.

Aury Lopes Jr. (2013) aponta como esta medida pode afetar o controle da vida cotidiana, inclusive por não haver limitação legal do período de comparecimento - se semanal, diário, mensal etc. Apesar de a prática judiciária reduzir o cumprimento a uma assinatura da pessoa investigada ou acusada em uma planilha com seu nome ${ }^{26}$ - ignorando a

25 Rio Grande do Sul, Paraíba, Tocantins, Santa Catarina e São Paulo - e no Distrito Federal.

26 Momento em que se aproveita para garantir abreviar o processo de cumprimento de atos processuais, como por exemplo, mandados de citação e intimações. 
parte de "informar e justificar atividades" - está legitimada uma carga de possibilidades de vigilância mediada pelo poder judiciário, que pode se concretizar, a depender de como se desenhe as atividades das equipes de atenção psicossocial. Segundo a Resolução 213/2015 do CNJ, a Central Integrada de Alternativas Penais deve manter relatórios reportando ao judiciário suas atividades de fiscalização do controle e encaminhamentos à assistência social.

Em geral, a aplicação das medidas cautelares alternativas não costuma ser fundamentada nas decisões, não se encontrando as razões que levaram os juízes a decidir por elas, dentro dos critérios legais do art. 282 do CPP e das finalidades específicas ${ }^{27}$ que constam em algumas das cautelares diversas do art. 319 do CPP (FERNANDES; DUCLERC, 2020; VASCONCELLOS, 2013). No I FONAPE, o CNJ havia fixado enunciados para determinar que a análise da liberdade plena deveria anteceder à da liberdade condicionada, além de exigir uma fundamentação específica para cada medida cautelar aplicada ${ }^{28}$.

Em relação ao universo de análise da pesquisa, metade das decisões justificaram, ainda que de forma genérica, a imposição de cautelares e, embora proferidas por juízes diferentes, as redações são idênticas neste ponto. Quando houve fundamentação expressa na decisão para aplicação das cautelares, com a exceção de um caso, ela se referiu a uma necessidade de garantia da ordem pública, vinculada a garantir a futura aplicação da lei penal ou garantir a persecução penal. Em que pese a inconstitucionalidade da "ordem pública" (LOPES JR., 2013), mesmo quando utilizada junto a estes argumentos, haveria a necessidade de demonstração concreta que a liberdade plena pudesse impedir o regular processamento ou eventual cumprimento de pena, sob pena de não existir uma cautelaridade.

27 A "proibição de se ausentar da Comarca" apresenta uma finalidade instrumental específica (necessidade ou conveniência da instrução criminal). O "comparecimento periódico em juízo" e o" recolhimento domiciliar" noturno não acrescentam finalidades particulares. A "proibição de manter contato com uma pessoa determinada" não deixa de demandar uma finalidade de cautela probatória, diante do lugar que a vítima tradicionalmente ocupa no processo penal.

Desde a Lei 13.964 de dezembro de 2019, o CPP explicita isso no artigo $282, \S 6^{\circ}$. 
O Superior Tribunal de Justiça (STJ) já elaborou o Informativo Jurisprudencial $\mathrm{n}^{\circ} 411$, em 2009, apresentando uma tese com base em diversos julgados na qual um estrangeiro sem bens, trabalho e família no país não pode sofrer presunção sumária de fuga ${ }^{29}$. O então relator da Operação Lava Jato no STF, ao rechaçar um argumento de presunção abstrata de fuga, decidiu, em 2017, no Habeas Corpus 127.186, que "o fato de o agente ser dirigente de empresa que possua filial no exterior, por si só, não constitui motivo suficiente para a decretação da prisão preventiva”. Mas, na era do monitoramento incessante à distância, para os sujeitos historicamente associados à "má” circulação, não ter um endereço para servir ao controle pode ser visto como algo fatal, um indício puro e simples de fuga.

Isso passa longe das diretrizes do Protocolo I da Resolução 213 do CNJ, que ao tentar limitar a extensão da aplicação das medidas, pretende assegurar, no item $X$, a não penalização da pobreza, especialmente no caso de situação de rua, em que "a conveniência para a instrução criminal ou a dificuldade de intimação para comparecimento a atos processuais não é circunstância apta a justificar a prisão processual ou medida cautelar".

Em um dos casos do universo de análise, Adriano ${ }^{30}$ foi solto em audiência após os atores institucionais concordarem que o fato imputado não passava de uma contravenção penal, em vez de um roubo, como sustentava a polícia. Os argumentos expostos para as cautelares alternativas não encobrem a automaticidade da sua aplicação. Uma vez selecionado pelas agências criminalizantes, seja por qual motivo for, independente da reiteração, já se abre espaço para expandir o controle em liberdade. Apesar de constar no APF o indicativo de uma situação transitória da rua, em audiência não foi revelada essa informação. O peso da reiteração se percebe na forma que o juiz avalia a sua liberdade: não pelo fato de a contravenção penal não permitir uma custódia cautelar, mas pela ausência de registros criminais:

29 Disponível: https://ww2.stj.jus.br/jurisprudencia/externo/informativo/?a$\mathrm{cao}=$ pesquisar\&livre=PRESUN\%C7\%C3O+DE+FUGA\&operador=e\&b=INFJ\&thesaurus=JURIDICO\&p=true. Acesso em 07.01.2018.

30 Os nomes citados ao longo das referências aos dados de campo são apenas representativos, a fim de preservar a identidade das pessoas. 
Os depoimentos e documentos juntados às folhas 01/32, colhidos no auto de prisão em flagrante revelam que as condições pessoais dos autuados conduzem a uma medida judicial alternativa à prisão, vez que tecnicamente primários, Adriano sequer registra passagens por delegacias, além de possuírem (sic) endereço certo, apresentando-se a concessão de liberdade provisória como a medida mais adequada à hipótese. Impõe-se, todavia, a aplicação das medidas cautelares diversas da prisão, a fim de resguardar-se a futura aplicação da lei penal, se for o caso, e de evitar prejuízo à instrução do processo judicial, garantindo-se a ordem pública, e adotando-se a devida proporcionalidade entre o que o caso apresenta e a medida judicial decretada. Por tais razões, aplico em desfavor dos autuados as medidas cautelares previstas no art. 319 do CPP, quais sejam, comparecimento bimenstral (sic) em juízo, para informar e justificar as suas atividades, proibição de ausentar-se da Comarca em que estiver residindo quando a permanência seja conveniente ou necessária para a investigação ou para a instrução, recolhimento domiciliar noturno das $22 \mathrm{hs}$ às 06hs, além do encaminhando dos autuados ao Programa ‘Corra para o Abraço' (grifamos).

A negação ao acesso à justiça e os processos de criminalização fazem o sistema de justiça criminal ser o único ramo do judiciário que se aproxima da população de rua. Quem vive na rua quando pensa em judiciário pensa primeiro em justiça criminal, em risco à liberdade. $\mathrm{O}$ mecanismo de controle à distância, às vezes silencioso e inerte, revela sua força quando ocorre uma prisão, seja por um fato novo ou por algum processo anterior, que a pessoa mal teve condições de acompanhar, pelas dinâmicas da vida na rua. Muitas pessoas convivem com processos criminais em curso ou mesmo execuções penais em andamento, não raro com sentenças transitadas em julgado, sem que elas saibam disso. Segundo uma supervisora do Programa Corra Pro Abraço (ROCHA, 2018), 57\% das demandas dos assistidos são referentes à justiça, muitas delas relacionadas a medidas cautelares ${ }^{31}$.

31 O Programa busca oferecer acolhimento a pessoas em situação de violação de direitos e demandas psicossociais e, através de uma atuação em rede, viabiliza ações de promoção de cidadania primordialmente nas esferas da saúde, da justiça, da assistência social e da educação e da justiça). Essa constatação da supervisora levou a criar uma equipe no NPF, em 2016, com a finalidade 
A prisão em flagrante por um novo crime parece a principal forma de se cumprir indiretamente um mandado de prisão por descumprimento de medida cautelar alternativa ou por condenação em ação penal e driblar o "endereço incerto" que frustra algumas criminalizações secundárias. $\mathrm{O}$ discurso da "insuficiência das cautelares" tenta ocultar o próprio sucesso de funções latentes das alternativas que reforçam a instituição prisional, com uma concreta possibilidade de voltar à prisão que se mantém sempre presente (COHEN, 1979).

Além da reiteração delitiva, o discurso de que as alternativas à prisão foram desrespeitadas foi bastante utilizado nas manifestações dos atores jurídicos. As pessoas em situação de rua - além de evitar ir à justiça, a qual associam primeiramente à prisão - não têm muitas possibilidades de deslocamento periódico de ida e retorno, seja mensal ou trimensal, ao bairro de Sussuarana, quase ao norte da região do Miolo de Salvador, onde fica o Fórum Criminal. As medidas, ao serem aplicadas independente da sua possibilidade de cumprimento diante das condições das pessoas, legitimam a manutenção na prisão por um fato posterior, mesmo que seja um furto sem prejuízo, protagonista nas trajetórias de criminalização analisadas $^{32}$.

As medidas cautelares perdem seu ideal de alternativa ao se referenciar constantemente à prisão. $\mathrm{O}$ sucesso, o fracasso e até a resposta a ambos giram em torno do cárcere. No contexto de criminalização da população de rua, a liberdade condicionada é muitas vezes uma prisão retardada. Para além da benevolência, a boa "chance” de deixar alguém em liberdade, as funções da prisão são reafirmadas (especialmente de

inicial de evitar uma maior fragilização dos vínculos e o isolamento de algum assistido eventualmente preso, ou possibilitar o início de um novo contato para acompanhamento na rua.

$32 \mathrm{Na}$ análise dos dados documentais, o furto foi o protagonista nas trajetórias de criminalização, entre materiais de alumínio, ferro ou cobre que encontram e alimentos que buscam. As prisões anteriores apresentam muitas semelhanças entre si e, em alguns casos, se tratam de uma habitualidade de crimes sem prejuízo em estabelecimentos alimentícios ou lojas, nas ruas ou em shoppings. Manoel, Humberto e Airton se sobressaem na quantidade de vezes em que foram presos de forma idêntica durante a subtração de bens alimentícios ou de higiene pessoal em estabelecimentos privados. Latas de azeite, chocolates, bebidas, carnes, queijos, entre outros, quase sempre imediatamente recuperados. 
contenção, expressamente defendida por promotores e juízes na prisão preventiva), de modo que a rede da punição se expande, afinando a malha (COHEN, 1979). A antecipação punitiva através da prisão preventiva, no contexto da governamentabilidade neoliberal, ganha um plus, com os efeitos punitivos das cautelares diversas, se não imediatos, a médio prazo.

Em vez de uma simples pena material aplicada desde já, a custódia cautelar pode configurar uma espécie de "prisão a médio prazo", na qual a prisão é ideologicamente reforçada com o "fracasso" programado de cautelares inexequíveis a quem vive na rua e está fora do padrão de inserção no capital. Este pressupõe uma territorialização fixa e sob os paradigmas liberais, bem como um trabalho fixo. A lógica de aplicação de medida alternativa que tende a um insucesso, com superveniência da prisão, se apresenta como um mecanismo de controle articulado à transitoriedade que é própria do viver e da circulação da população de rua. O que ela tem de quase certa, diante da precariedade da liberdade dos corpos negros com territorializações transitórias, pode ter de mais dura, uma vez relegitimada (ROMÃO, 2019). Revertê-la pode ser mais difícil, já que a pessoa desperdiçou suas "chances", demonstrando que as alternativas foram insuficientes para conter o que então se constata, a sua "personalidade voltada para o crime".

A ampliação das possibilidades de encarceramento adquire uma dimensão menos relacionada ao fato imputado que as condições de vida das pessoas e quem elas são, o que as coloca em exposição acentuada à criminalização secundária. Logo, há um efeito latente de "prisão a médio prazo" nessas medidas cautelares aplicadas sem proporcionalidade, seguindo o binômio prisão-condição à liberdade. Se uma medida desencarceradora já se mostraria suspeita pela pergunta se a prisão pode acontecer, uma vez ela aplicada, mais grave parece ser a situação das cautelares impostas à população de rua, onde a pergunta se transforma em quando ela vai acontecer. Como diz Nilo Batista (2011, p. 08), "toda legitimação do poder punitivo acaba repercutindo no lombo estereotipado dos suspeitos de sempre”.

\section{Considerações finaIS}

O desenvolvimento do trabalho, como mencionado acima, partiu da pergunta seguinte de pesquisa: como ocorre a aplicação de medidas 
cautelares pessoais nos encontros presenciais entre atores jurídicos e pessoas em situação de rua em audiências de custódia? O caminhar da pesquisa permitiu inferir que a finalidade de redução do encarceramento deve ser pensada de forma dinâmica, especialmente pela regra de se condicionar a liberdade às medidas cautelares pessoais, com o risco perene de prisão preventiva e com o hábito do judiciário de não conceder a liberdade plena diante do que entende como reiteração criminosa.

A observação da experiência dos "paredões" no NPF contribuiu para ampliar os entrelaçamentos das duas técnicas de pesquisa adotadas. O estudo dos APFs e de outros documentos jurídicos adquiriu outro nível de desconfiança, ao tempo que a mediação das narrativas e dos discursos de outros atores nos processos mostrou como as audiências de custódia fraturam silêncios, mas também produz inúmeros outros. $\mathrm{O}$ judiciário se vale de um controle da escrita que blinda o poder punitivo e instrumentaliza o pacto de silenciamento que encobre privilégios e violências. Na gestão da circulação, mediada entre prisão preventiva e cautelares diversas, os "paredões" são um mecanismo governamental que, sob o discurso da "chance", expande o controle, tanto nas inquirições e reprimendas informais quanto na aplicação arbitrária de cautelares diversas.

A forma de produção de documentos em audiências de custódia serve à legitimação do sistema punitivo e do status quo que orienta a operacionalidade real das agências de criminalização secundária. O documento que mais se espera no NPF, a decisão judicial, tende a ser repetitivo, como já o era antes dos encontros presenciais entre juízes e pessoas presas. Aproveitando diversos parágrafos de outras decisões, em pouco espaço, individualiza, quando o faz, a fundamentação sobre a homologação do flagrante e a aplicação de cautelares.

Nesse cenário, a forma que se chega à aplicação de medidas cautelares diversas da prisão em espécie não só desconsidera um debate sério sobre cautelaridade. Há tanto a ausência de fundamentação escrita quanto a revelação, na audiência de custódia, de intenções, tradicionalmente ocultas no discurso formal dos documentos judiciais, mobilizadas arbitrariamente como a real justificativa para restringir liberdade, embora isso seja camuflado pela ideia de concessão de uma "chance", uma benesse a quem não teve a prisão mantida. 
O processo de decisão sobre a liberdade, entre os debates orais e os atos informais na sala de audiências, também se vale da construção etiológica de perfis fadados à contenção, de imediato ou a médio prazo, traçados pelas narrativas processuais. As pessoas em situação de rua se forem presos por outro fato, não importa o qual nem suas circunstâncias, o que resta é destino do cárcere cujo uso não se descarta. A reiteração criminosa que encobre a exposição acentuada ao encarceramento legitima o agravamento das condições de vida na rua, servindo perversamente de argumento para restringir mais direitos em liberdade, especialmente no verão, sem que se fundamente no suposto fato criminoso ou atenda o requisito da cautelaridade.

Uma compreensão crítica acerca dos registros criminais evidencia que este argumento não contribui para fazer que medidas cautelares sejam de fato uma alternativa à prisão. Do comparecimento em juízo e proibição de frequentar festas ao recolhimento noturno ou monitoramento eletrônico, as possibilidades de detenção têm se ampliado e se aproximam de distintas formas da população de rua.

A função da cautelar alternativa como punição antecipada abre espaço para uma maior legitimação e reforço da via prisional, que serve a estratégias variadas de controle da circulação urbana. Mesmo que a pessoa tenha cumprido parcialmente ou mesmo todas as condições em liberdade, uma nova prisão continuará a oferecer a confortável constatação de que as cautelares foram insuficientes para inibir o "comportamento voltado para o crime" daqueles que mais uma vez vão presos.

A prisão cautelar está sempre em órbita, especialmente para a população de rua. A prisão que volta com força, não mais preocupada em corrigir - tarefa delegada às equipes multiprofissionais (BATISTA, 2003b) - procura garantir uma contenção, ou seja, uma neutralização justificada na redutiva análise positivista em torno da "reiteração delitiva" de alguém que não se corrigiu pelas medidas cautelares diversas.

A lógica da "prisão a médio prazo" coloca as cautelares diversas e a prisão preventiva como eixos que hoje estão indispensavelmente conectados no controle da circulação da população de rua, atualizando os mecanismos de controle antinegro que precariza as liberdades, na gestão da coexistência densa na cidade negra de Salvador. Os pequenos furtos servem de instrumento para a gestão populacional entre a prisão-depósito 
e a aplicação de medidas cautelares arbitrariamente impostas, que servem a funções ocultas e atendem a demandas por ordem (BATISTA, V., 2011).

As medidas cautelares diversas da prisão não produzem apenas efeitos repressivos, mas em sua função "positiva", de configurar verticalmente as relações sociais, assume funções ocultas de marcadores de espaço (FOUCAULT, 2014; MBEMBE, 2017). Esse controle diferenciado depende de algumas variáveis que podem ser mais exploradas de forma mais aprofundada em outra pesquisa. Dentro das limitações desta pesquisa, no verão, pode-se perceber que a cautelar de proibição de frequentar festas populares e até a aplicação de fiança, sabendo os atores processuais da situação de rua dos seus destinatários, agem sob distintas formas para limitar a circulação em liberdade.

A conjuntura atual, de maior recrudescimento punitivo, enfrenta uma pandemia com consequências ainda incertas para o processo penal. Inicialmente, o CNJ - por meio da Recomendação $n^{\circ} 62$ e da aprovação do ato normativo 4117/63 em 10 de julho de 2020 - contribuiu para evitar que as audiências de custódia fossem realizadas por videoconferência. A própria continuidade das audiências de custódia, alvo constante de propostas de retrocesso, está ameaçada, em um momento chave para as persistentes tentativas de tornar regra o meio audiovisual.

As reflexões sobre o tratamento objetificado, que passou dos papeis trocados em plantões judiciais para salas de audiências, contribuem para complexificar os desafios em torno da redução da lógica do cárcere e da promoção de direitos também em situações de não realização de audiência de custódia, uma vez que atravessam de forma decisiva o processo de tomada de decisão sobre a aplicação de medidas cautelares.

\section{REFERÊNCIAS}

ALEXANDER, Michelle. The new Jim Crow: Mass incarceration in the age of color blindness. New York: The New Press, 2012.

ALMEIDA, Silvio Luiz de. O que é racismo estrutural?. Belo Horizonte: Letramento, 2018.

AUGUSTO, Acácio. Para além da prisão-prédio: as periferias como campos de concentração a céu aberto. Cadernos Metrópole, São Paulo, v. 12, n. 23, p. 263276, jan./jun., 2010. 
BATISTA, Vera Malaguti. O medo na cidade do Rio de Janeiro: dois tempos de uma história. Rio de Janeiro: Revan, 2003a.

BATISTA, Vera Malaguti. Difíceis ganhos fáceis: drogas e juventude pobre no Rio de Janeiro. Rio de Janeiro: Revan, 2003b.

BATISTA, Vera Malaguti. Introdução crítica à criminologia brasileira. Rio de Janeiro: Revan, 2011.

BATISTA, Nilo. Sobre el filo de la navaja. Revista EPOS, Rio de Janeiro; v. 2, n. 1, jan./jun., 2011.

BERGALLI, Roberto. A instância judicial. In: BERGALLI; Roberto; RAMIREZ, Juan Bustos. O pensamento criminológico II: estado brasileiro. Rio de Janeiro: Revan, 2015. BERTÚLIO, Dora Lúcia de Lima. Direito e relações raciais: uma introdução crítica ao racismo. Dissertação (Mestrado em Direito). Universidade Federal de Santa Catarina, Florianópolis, 1989.

BEVILÁCQUA, Ciméia. Etnografia do Estado: algumas questões metodológicas e éticas. Revista Campos, Curitiba, n. 3, 2003. http://dx.doi.org/10.5380/cam. v3i0.1587

CARVALHO, Salo. Substitutivos penais na era do grande encarceramento. In: Depois do grande encarceramento. Rio de Janeiro: Revan, 2010a.

CARVALHO, Salo de. O papel dos atores do sistema penal na era do punitivismo. Rio de Janeiro: Lumen Juris, 2010b.

CASTRO, Pedro Machado de Almeida. Medidas cautelares pessoais, poder geral de cautela e a taxatividade mitigada. Revista Brasileira de Direito Processual Penal, Porto Alegre, v. 3, n. 2, p. 691-716, mai./ago. 2017. https://doi.org/10.22197/ rbdpp.v3i2.60

CELLARD, André. A análise documental. In: POUPART et al. A pesquisa qualitativa: enfoques epistemológicos. Petrópolis: Vozes, 2014.

COHEN, Stanley. The punitive city: notes on the dispersal of social control. Contemporary Crises, v. 3, p. 339-363, 1979. https://doi.org/10.1007/BF00729115

CONECTAS Direitos Humanos. Tortura blindada: como as instituições do sistema de justiça perpetuam a violência nas audiências de custódia. 2016.

CONSELHO NACIONAL DE JUSTIÇA. Resolução n²13/2015. Disponível em: < http://www.cnj.jus.br/busca-atos-adm?documento=3059> Acesso em 09.05.2016. CONSELHO NACIONAL DE JUSTIÇA. Recomendação $n^{\circ}$ 62/2020. Disponível em: https://www.cnj.jus.br/wp-content/uploads/2020/03/62-Recomenda\%C3\%A7\%C3\%A3o.pdf. Acesso em 14.07.2020. 
CONSELHO NACIONAL DE JUSTIÇA. Audiência de custódia, prisão provisória e medidas cautelares: obstáculos institucionais e ideológicos à efetivação da liberdade como regra. Disponível em: http://www.cnj.jus.br/files/conteudo/ arquivo/2017/10/4269e81937d899aa6133ff6bb524b237.pdf. 2018. Acesso em 23 jan. 2019.

CORDEIRO, Néfi; COUTINHO, Nilton Carlos de Almeida. A audiência de custódia e seu papel como instrumento constitucional de concretização de direitos. Revista de Estudos Constitucionais, Hermenêutica e Teoria do Direito (RECHTD), a. 10, v.1, p. 76-88, jan./abr.2018. https://doi.org/10.4013/rechtd.2018.101.06. CRESSWELL, John. Investigação qualitativa e projeto de pesquisa: escolhendo entre cinco abordagens. Tradução de Sandra Mallmann da Rosa. 3a ed. Porto Alegre: Penso, 2014.

DEFENSORIA PÚBLICA DO ESTADO DA BAHIA. Relatório das audiências de custódia na comarca de Salvador (anos 2015 a 2018). Salvador: ESDEP, 2019.

DEPARTAMENTO PENITENCIÁRIO NACIONAL. Levantamento Nacional de Informações Penitenciárias (INFOPEN). Brasília. Jun. 2014. Acesso em 08/12/2017.

DEPARTAMENTO PENITENCIÁRIO NACIONAL DO MINISTÉRIO DA JUSTIÇA (DEPEN). Levantamento Nacional de Informações Penitenciárias. DEPEN: Brasília, Junho, 2016. Disponível em: http://www.justica.gov.br/news/ha-726-712-pessoas-presas-nobrasil/relatorio_2016_junho.pdf. Acesso em 08.12.2017.

DEPARTAMENTO PENITENCIÁRIO NACIONAL DO MINISTÉRIO DA JUSTIÇA (DEPEN). Levantamento Nacional de Informações Penitenciárias. DEPEN: Brasília, 2018. Disponível em: http://depen.gov.br/DEPEN/depen/sisdepen/infopen-mulheres/infopenmulheres_arte_07-03-18.pdf. Acesso em 14.07.2020.

DEPARTAMENTO PENITENCIÁRIO NACIONAL DO MINISTÉRIO DA JUSTIÇA (DEPEN). Levantamento Nacional de Informações Penitenciárias. DEPEN: Brasília, 2019. Disponível em: http://depen.gov.br/DEPEN/depen/sisdepen/infopen/ relatorios-sinteticos/relatorios-sinteticos. Acesso em: 18 jul. 2020.

FANON, Frantz. Pele Negra, Máscaras Brancas. Salvador: EDUFBA, 2008.

FERNANDES, Daniel Fonseca; DUCLERC, Elmir. Audiência de custódia e fundamentos das decisões judiciais: uma análise em dois tempos, 2020. (não publicado).

FERREIRA, Carolina Costa. Audiência de custódia: instituto de descarcerização ou de reafirmação de estereótipos?. Revista Justiça do Direito. v, 31, n.2, p.279-303, mai./ago., 2017. http://dx.doi.org/10.5335/rjd.v30i2.7153.

FOUCAULT, Michel. Vigiar e Punir: nascimento da prisão. 42a ed. Petrópolis: Vozes, 2014. 
FOUCAULT, Michel. Segurança, território e população. São Paulo: Martins Fontes, 2008.

INSTITUTO DE DEFESA DO DIREITO DE DEFESA (IDDD). O fim da liberdade: a urgência de recuperar o sentido e a efetividade das audiências de custódia. 2019. Disponível em: http://www.iddd.org.br/wp-content/uploads/2020/07/ OFimDaLiberdade_completo.pdf. Acesso em 06.11.2020.

KARAM, Maria Lúcia. Dispositivos legais desencarceradores. In: Vera Malaguti Batista e Pedro Abramovay (orgs.). Depois do grande encarceramento. Rio de Janeiro: Revan, p. 341-350, 2010.

KULLER, Laís; DIAS, Camila. O papel do preso nas audiências de custódia: Protagonista ou marginal?. Dilemas - Revista de Estudos de Conflito e Controle Social, Rio de Janeiro, v. 12, n. 2, mai./ago., pp. 267-287, 2019.

LAGES, Lívia Bastos; RIBEIRO, Ludmila. Os determinantes da prisão preventiva na Audiência de Custódia: reforço de estereótipos sociais?. Revista Direito GV, São Paulo, v. 15, n. 3, 2019. http://dx.doi.org/10.1590/2317-6172201933

LOPES JR., Aury. Prisões cautelares. 4. ed. São Paulo: Saraiva, 2013.

MARCONI, Marina de Andrade; LAKATOS, Eva. Fundamentos de Metodologia Científica. 5a ed. São Paulo: Atlas, 2003.

MBEMBE, Achille. Crítica da razão negra. 2a ed. Lisboa: Antígona, 2017.

MELOSSI, Dario. Está em crisis la criminologia crítica?. In. MELOSSI, D. Delito, pena y control social: um enfoque sociológico entre estrutura e cultura. Buenos Aires: Ad-Hoc, 2012.

MUNANGA, Kabengele. Uma abordagem conceitual das noções de raça, racismo, identidade e etnia. $3^{\circ}$ Seminário Nacional Relações Raciais e Educação. Rio de Janeiro, 2003.

OLIVEIRA; Fabiana. SILVA, Virgínia. Processos judiciais como fontes de dados: poder e interpretação. Sociologias, a. 7, n. 13, p.244-259, 2013. https://doi. org/10.1590/S1517-45222005000100010

PAIVA, Caio; LOPES JR, Aury. Audiência de custódia e a imediata apresentação do preso ao juiz: rumo à evolução civilizatória do processo penal. Revista Liberdades, n. 17, p. 11-23, set./dez. 2014.

PEIRANO, Mariza. Etnografia não é método. Horizontes Antropológicos, Porto Alegre, ano 20, n. 42, p. 377-391, jul./dez. 2014. http://dx.doi.org/10.1590/ S0104-71832014000200015. 
PIRES, Álvaro. Amostragem e pesquisa qualitativa: ensaio teórico e metodológico. In: POUPART, Jean et al (orgs.). A pesquisa qualitativa: enfoques epistemológicos. Petrópolis: Vozes, 2014.

PIRES, Thula. Do ferro quente ao monitoramento eletrônico: controle, desrespeito e expropriação de corpos negros pelo Estado brasileiro. In: FLAUZINA, Ana et al (orgs.). Discursos negros: legislação penal, política criminal e racismo. Brasília: Brado Negro, 2015.

PIRES, Thula. Criminologia crítica e pacto narcísico: por uma criminologia apreensível em pretuguês. RBCCRIM, São Paulo, v. 135, a. 25, p. 541-562, 2017.

PRADO, Geraldo. Sistema acusatório: a conformidade constitucional das leis processuais penais. 3a ed. Rio de Janeiro: Lumen Juris, 2005.

PROJETO AXÉ. Cartografias dos desejos e direitos: mapeamento e contagem da população em situação de rua na cidade de Salvador - Bahia. Salvador, 2017.

ROCHA, Lucineia. A atuação do Corra para o Abraço nas audiências de custódia. In: seminário audiências de custódia, Salvador, 2018. Disponível: https://www. youtube.com/watch?v=A_hWSz3Bs9o. Acesso em 6 jan. 2019.

ROMÃO, Vinícius de Assis. Entre a vida na rua e os encontros com a prisão: um estudo a partir das audiências de custódia. Dissertação (Mestrado em Direito). Universidade do Estado do Rio de Janeiro, Rio de Janeiro, 2019.

ROSÁRIO, Luan da Silva. Entre a cruz e a espada: a prática das audiências de custódia e da "audiência Paredão" no Núcleo de Prisão em Flagrante de Salvador. Monografia (Graduação em Direito). Universidade Federal da Bahia, Salvador, 2018.

SANTOS, Milton. O espaço do cidadão. 7a ed. São Paulo: EDUSP, 2014.

SOARES, Igor Alves Norberto. As medidas cautelares e a audiência de apresentação (audiência de custódia) no processo penal: enfrentamentos a partir da teoria do processo constitucional. Revista de Direito da Faculdade de Guanambi, v. 5, n. 1, p. 174-200, jan./jun. 2018. https://doi.org/10.29293/rdfg.v5i01.207

TEIXEIRA, Yuri Serra. Do grande encarceramento à audiência de custódia: reflexões etnográficas sobre a seletividade penal. Rio de Janeiro: Lumen Juris, 2019.

VALENÇA, Manuela Abath; MELLO, Marília Montenegro Pessoa de. "Pancada de amor não dói”: a audiência de custódia e a visibilidade invertida da vítima nos casos de violência doméstica. Revista Direito e Práxis, Rio de Janeiro, v. 11, n. 02, p. 1238-1274, 2020. https://doi.org/10.1590/2179-8966/2020/50471

VALOIS, Luís Carlos. Execução penal e ressocialização. São Paulo: Estúdio Editoores.com, 2015. 
VARGAS, João H. Por uma mudança de paradigma: antinegritude e antagonismo estrutural. In: FLAUZINA, Ana; VARGAS, João (Orgs.). Motim: Horizontes do genocídio antinegro. Brasília: Brado Negro, 2017.

VASCONCELLOS, Vinícius Gomes de. A inserção de medidas cautelares diversas no sistema processual penal brasileiro: entre a expansão do controle punitivo e sua limitação. Revista de Estudos Criminais. Porto Alegre, v. 11, n.51, p. 143-168, 2013.

ZAFFARONI, Eugênio R. O inimigo no Direito Penal. Rio de Janeiro: Revan, 2011. ZAFFARONI, Eugenio Raúl. Em busca das penas perdidas: a perda de legitimidade do sistema penal. 5a ed. Rio de Janeiro: Revan, 1991.

\section{Informações adicionais e declarações do autor}

Agradecimentos: O presente trabalho foi realizado com apoio da Coordenação de Aperfeiçoamento de Pessoal de Nível Superior Brasil (CAPES) - Código de Financiamento 001.

Declaração de conflito de interesses (conflict of interest declaration): o autor confirma que não há conflitos de interesse na realização das pesquisas expostas e na redação deste artigo.

Declaração de autoria e especificação das contribuições (declaration of authorship): todas e somente as pessoas que atendem os requisitos de autoria deste artigo estão listadas como autores; todos os coautores se responsabilizam integralmente por este trabalho em sua totalidade.

Declaração de ineditismo e originalidade (declaration of originality): o autor assegura que o texto aqui publicado não foi divulgado anteriormente em outro meio e que futura republicação somente se realizará com a indicação expressa da referência desta publicação original; também atesta que não há plágio de terceiros ou autoplágio. 
Dados do processo editorial

(http://www.ibraspp.com.br/revista/index.php/RBDPP/about/editorialPolicies)

- Recebido em: 19/07/2020

Equipe editorial envolvida

- Controle preliminar e verificação de plágio: 07/08/2020

- Avaliação 1: 17/08/2020

- Avaliação 2: 28/08/2020

- Avaliação 3: 29/08/2020

- Avaliação 4: 04/09/2020

- Decisão editorial preliminar: 05/10/2020

- Retorno rodada de correções 1: 04/12/2020

- Decisão editorial preliminar 2: 21/12/2020

- Retorno rodada de correções 2: 10/01/2021

- Decisão editorial final: 10/01/2021

\section{COMO CITAR ESTE ARTIGO:}

ROMÃO, Vinícius de Assis. A aplicação de medidas cautelares pessoais em audiências de custódia: um olhar a partir da prisão em flagrante de pessoas em situação de rua. Revista Brasileira de Direito Processual Penal, Porto Alegre, vol. 7, n. 1, p. 611-650, jan./abr. 2021.

https://doi.org/10.22197/rbdpp.v7i1.425

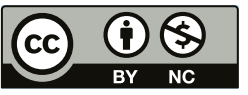

Esta obra está licenciada com uma Licença Creative Commons Atribuição-NãoComercial 4.0 Internacional. 